\title{
PENGARUH PERSEPSI SISWA SMASMK TENTANG PERAN GURU DAN PROFESI GURU TERHADAP MINAT SISWA MENJADI GURU
}

\author{
Rita Zahara \\ Universitas Langlangbuana Bandung \\ ritazaharara3110@gmail.com
}

\begin{abstract}
The purpose of this study is to describe the influence of high school / vocational high school students' perceptions about the role of the teacher and the teaching profession on the interest in becoming a teacher. The population in this study was all students of class XII in FKIP_UNLA partner schools, namely SMAN 8 Bandung, SMAN XI Bandung, SMKN 3 Bandung, and SMK Bandung Community Development, by using quota sampling. This type of research is quantitative research with correlation research methods. Data collection techniques were obtained using: Questionnaire, and interview, namely in the form of statements relating to the perceptions of high school / vocational students about the role of the teacher and the teaching profession the effect on student interest in becoming the teaching profession. Research results show that the perception of high school / vocational students about the role of teachers and the teaching profession contributes effectively to changes in the variable of student interest to become a teacher, and of these two variables the perception of students gives an influence on students' interest in becoming teachers.
\end{abstract}

Keywords: Persepsi siswa, profesi Guru, dan minat menjadi guru. (Student perceptions, Teacher profession, and interests in becoming a teacher.)

\begin{abstract}
ABSTRAK
Tujuan penelitian ini adalah untuk Mendeskripsikan pengaruh Persepsi siswa SMA/SMK tentang peran guru dan profesi guru terhadap minat menjadi Guru. Populasi dalam penelitian ini ini seluruh siswa kelas XII yang ada di sekolah mitra FKIP_UNLA yaitu SMAN 8 Bandung, SMAN XI Bandung, SMKN 3 Bandung, dan SMK Bina Warga Bandung, degan menggunakan sampling kuota. Jenis penelitian ini adalah penelitian kuatitatif dengan metode penelitian korelasi. Teknik pengumpulan data diperoleh dengan menggunakan: Angket, dan wawancara, yaitu berupa pernyataan yang berkaitan dengan persepsi siswa SMA/SMK tentang peran guru dan profesi guru pengaruhnya terhadap minat siswa menjadi profesi guru. Hasil penelitan menunjukan bahwa persepsi siswa SMA/SMK tentang peran guru dan profesi guru memberikan sumbangan efektik terhadap perubahan variable minat siswa menjadi guru, dan dari kedua variable persepsi siswa tersebut memberikan pengaruh terhadap minat siswa menjadi guru.
\end{abstract}

Keywords: Persepsi siswa, profesi Guru, dan minat menjadi guru. 


\section{A. Pendahuluan}

Guru merupakan bagian komponen pendidikan yang strategis, pendidikan pun tidak dapat berjalan tanpa peran seorang guru. Guru juga biasa disebut tombak proses pendidikan, yang mengantarkan anak didiknya menuju kesuksesan bagi pembangunan bangsa. Karena pentingnya peran guru, salah satu pakar pendidikan Nana Syaodih Sukmadinata berpendapat, bahwa seandainya tidak ada kurikulum, tidak ada ruang kelas dan prasarana belajar mengajar lainnya, namun ada guru, maka pendidikan dan pengajaran masih dapat berjalan, di samping itu pula, guru adalah pribadi yang dapat menentukan maju atau tidaknya sebuah bangsa dan peradaban manusia. Di tangan guru seorang anak yang awalnya tidak tahu apa-apa menjadi pribadi tahu, dan melalui bimbingan guru lahir generasi muda yang unggul, pandai dan berakhlak mulia. Dalam UndangUndang Guru dan Dosen (UUGD) Nomor 14 Tahun 2005 disebutkan bahwa guru adalah pendidik professional dengan tugas utama mendidik, mengajar, membimbing, mengarahkan, melatih, menilai dan mengevalusi peserta didik pada pendidikan anak usia dini jalur pendidikan formal, pendidikan dasar dan menengah. Dalam kontek ini guru dimaknai sebagai figur seorang pemimpin, sosok arsitektur yang dapat membentuk keperibadian dan watak peserta didik, mempunyai kekuasaan fundamental untuk membentuk dan membangun keperibadian peserta didik menjadi manusia yang berguna bagi agama, nusa, bangsa dan kehidupan sosial.

Tugas dan peran guru yang semakin bervariasi ini dirasakan menjadi sesuatu yang tidak mudah, menuntut guru memiliki berbagai kompetensi, yaitu kompetensi, paedagogis, kompetensi professional, kompetensi Individual dan kompetensi sosil, hal ini menuntuk guru memiliki Kualifikasi akademik yang sesuai dengan bidangnya, dan menuntut guru terus meningkatkan kemampuannya untuk mendapatkan hasil yang optimal dalam menjalankan tugas dan perannya tersebut. (Rina Febriana, 2018 )

Profesi Guru yang menuntuk banyak kemampuan yang harus dimiliki dan dilaksanakan oleh sesorang guru, sehubungan dengan tugas mulia ini menjadikan tugas ini 
bukanlah tugas yang mudah untuk dilaksanakan, sehingga hal ini dapat menjadi penyebab kurang berminatnya Siswa SMA/ SMK untuk melanjutkan pendidikan pada bidang pendidikan dan keguruan, selain itu hasil pengamatan terhadap siswasiswi SMA/SMK yang ada di perkotaan kurang berminat untuk menjadi seorang guru, dan dari artikel terkait GURU yang ditulis Alfian Putra Abdi, menyatakan bahwa Kementerian Pendidikan dan Kebudayaan (Kemendikbud) baru pada tahun 2019, menyertakan tes angket kepada peserta Ujian Nasional Berbasis Komputer (UNBK) tingkat SMA dengan tujuan mengkaji informasi non-kognitif siswa. Terdapat satu angket yang diperuntukkan untuk mengetahui citacita peserta didik yang disebar kepada 512.500 siswa di 8.549 SMA/MA. Masing-masing sekolah, menyertakan maksimal 60 siswa untuk menjawab. Hasilnya mencatat 89 persen siswa bercita-cita sebagai pengusaha segala bidang dan presiden. Sekitar 11 persen yang bercita-cita menjadi guru dengan mayoritas perempuan. Namun, dari data angket tersebut, 11 persen siswa yang bercita-cita menjadi guru adalah mereka yang berada dalam kelompok nilai tidak maksimal. (Alfian Putra Abdi - 8 Mei 2019)

Adapun factor penyebabnya belum diketahui secara pasti. Apakah siswa mengangap profesi guru itu profesi yang sulit, atau profesi yang kurang bergengsi. Pengetahuan tentang peran guru dan profesi guru ini apakah sudah atau belum dipahami oleh masyarakat luas pada umumnya dan siswa SMA/SMK pada khususnya, yang menjadi generasi penerus bangsa dimasa depan khususnya dalam bidang pendidikan, dihawatirkan persepsi siswa terhadap profesi guru ini tidak dipahami secara menyeluruh, sehingga profesi guru ini menjadi tidak popular dimata siswa SMA/SMK yang berniat melanjutkan ke jenjang yang lebih tinggi. Tujuan penelitian ini untuk mengetahui pengaruh persepsi siswa SMA/SMK tentang peran guru dan profesi guru terhadap minat siswa menjadi guru.

Siswa SMA/SMK yang akan melajutkan ke jenjang pendidikan tinggi yang merupakan generasi penerus bangsa diharapkan terpanggil jiwanya untuk mempelajari bidang kajian pendidikan yang akan menjadi agent perubahan bagi 
kemajuan pendidikan di negara Indonesia. Diperlukan upaya-upaya untuk mengingatkan dan memberikan motivasi kepada generasi muda untuk mendalami kajian IImu Pendidikan sebagai bentuk tanggung jawab untuk masa depan pendidikan di negara kita ini.

Salah satu upaya sebagai langkah awal adalah dengan melakukan penelitian tentang persepsi siswa SMA/SMK tentang profesi guru, sehingan kita dapat melihat sejauhmana siswa SMA/SMK ini mengetahui tentang profesi guru, selanjutnya dengan persepsi yang mereka ketahui apakah hal tersebut dapat meningkatkan minat mereka menjadi guru.

Berdasarkan latar belakang masalah di atas, masalah penelitian difokuskan pada Persepsi siswa SMA/SMK tentang peran guru dan profesi guru terhadap minat menjadi Guru, tujuan penelitian Tujuan penelitian ini adalah untuk Mendeskripsikan pengaruh Persepsi siswa SMA/SMK tentang peran guru dan profesi guru terhadap minat menjadi Guru

\section{B. Metode Penelitian}

Metode yang digunakan dalam penelitian ini menggunakan metode kuantitatif Korelasi berganda, dengan mengukur pengaruh antara Variable persepsi siswa tentang peran guru (X1), dan variable persepsi siswa tentang profesi guru (X2), dengan variable minat siswa menjadi guru $(\mathrm{Y})$, Pendekatan ini memberikan manfaat untuk mengetahui persepsi siswa SMA/SMK tentang peran guru dan profesi guru terhadap minat siswa untuk menjadi guru, hal ini dapat memberikan masukan pada LPTK untuk dapat melakukan tindakan dan keputusan terbaik untuk pengembangan lembaga.

Populasi adalah keseluruhan sobyek penelitian. Apabila seseorang ingin meneliti semua elemen yang ada dalam wilayah penelitian, maka penelitiannya merupakan penelitian populasi. Studi atau penelitiannya juga disebut studi populasi atau studi sensus (Arikunto,2010). Populasi dalam penelitian ini seluruh siswa kelas XII yang ada di sekolah mitra FKIP_UNLA yaitu Sam SMAN 8 Bandung ada 439 siswa, SMAN XI Bandung ada 453 siswa, SMKN 3 Bandung ada 693 siswa, dan SMK Bina Warga Bandung ada 363, jadi 
total populasi ada 1948 siswa. Teknik pengambilan sampel yang digunakan adalah Sampling kuota dengan diberikan jatah atau quorum tertentu terhadap kelompok. Pengambilan sampel dari populasi, sekitar 147 siswa, dengan perincian sebagai berikut : SMAN 8 Bandung 33 siswa, SMAN 11 Bandung 34 siswa, SMKN 3 Bandung 52 siswa, SMAN 12 Bandung 28 siswa.

Teknik Analisis

Data menggunakan Uji Asumsi Klasik yang terdiri dari : 1). Uji Normalitas, dilakukan untuk mengetahui semua variabel penelitian berdistribusi normal atau tidak. Uji normalitas diujikan pada masing-masing variabel. Pengujian normalitas menggunakan teknik analisis Kolmogorov-Smirnov. Data dikatakan berdistribusi normal apabila nilai signifikansi $>\alpha=0,05.2$ ). Uji Multikolinieritas, bertujuan untuk menguji ada atau tidaknya korelasi antar variabel bebas. Untuk melakukan uji multikolinieritas dalam model regresi penelitian ini akan dilihat dari nilai tolerance dan Variance Inflantion Factor (VIF). Tolerance mengukur variabel bebas terpilih yang tidak dapat dijelaskan variabel bebas lainnya. Nilai tolerance yang rendah sama dengan nilai VIF yang tinggi dan menunjukkan multikolinieritas yang tinggi, karena VIF = 1/tolerance. Nilai yang umum dipakai adalah nilai tolerance $>0,1$ dan nilai VIF $<10$, menunjukkan tidak terjadi multikolinieritas. (Ghozali, 2006: 103)3). Uji Heteroskedastisitas, untuk menguji dalam model regresi terjadi ketidaksamaan varians dan residual atau tidak dalam satu pengamatan ke pengamatan yang lain. Jika varians dan residual tetap maka disebut homoskedastisitas, sebaliknya jika varians dan residual berbeda maka disebut heteroskedastisitas. Model regresi yang baik adalah yang tidak terjadi heteroskedastisitas. Dalam penelitian ini, uji heteroskedastisitas menggunakan Glejser untuk mengetahui tidak adanya heteroskedastisitas ditunjukkan dengan tidak ada satupun variabel independen yang signifikan secara statistik mempengaruhi variabel dependen nilai Absolut Residual. Hal ini terlihat dari probabilitas signifikansinya $>0,05$. dan 4). Uji Autokolerasi. bertujuan untuk mengetahui apakah dalam sebuah model regresi linier ada kolerasi antara kesalahan penganggu pada 
periode $\mathrm{t}$ dengan kesalahan pada periode $\mathrm{t}-1$ (sebelumnya). Jika terjadi kolerasi, maka dinamakan ada problem autokorelasi. Tentu saja model regresi yang baik adalah regresi yang bebas dari autokolerasi (Singgih Santoso, 2012:241). Pada prosedur pendeteksian masalah autokolerasi dapat digunakan besaran Durbin-Waston. Untuk memeriksa ada tidaknya autokolerasi, maka dilakukan uji Durbin-Watson.

Uji Hipotesis Analisis Korelasi Berganda (Simultan) digunakan untuk mengetahui derajat atau kekuatan hubungan antara seluruh variabel $X$ terhadap variabel $Y$ secara bersamaan. Pengujian Hipotesis menggunakan Uji t ( uji Parsial) dan uji F ( Uji Simultan) untuk menguji signifikasi pengaruh Persepsi Siswa SMA/SMK tentang peran Guru dan Profesi Guru terhadap Minat siswa menjadi Guru.

\section{C.Hasil Penelitian dan Pembahasan}

Hasil analisis data terdiri atas statistik deskriptif, hasil uji asumsi klasik dan hasil uji hipotesis penelitian. Berikut rincian masingmasing bagian:

Uji asumsi klasik
1. Uji Normalitas, sampel yang digunakan mempunyai distribusi normal untuk masing2 variabel

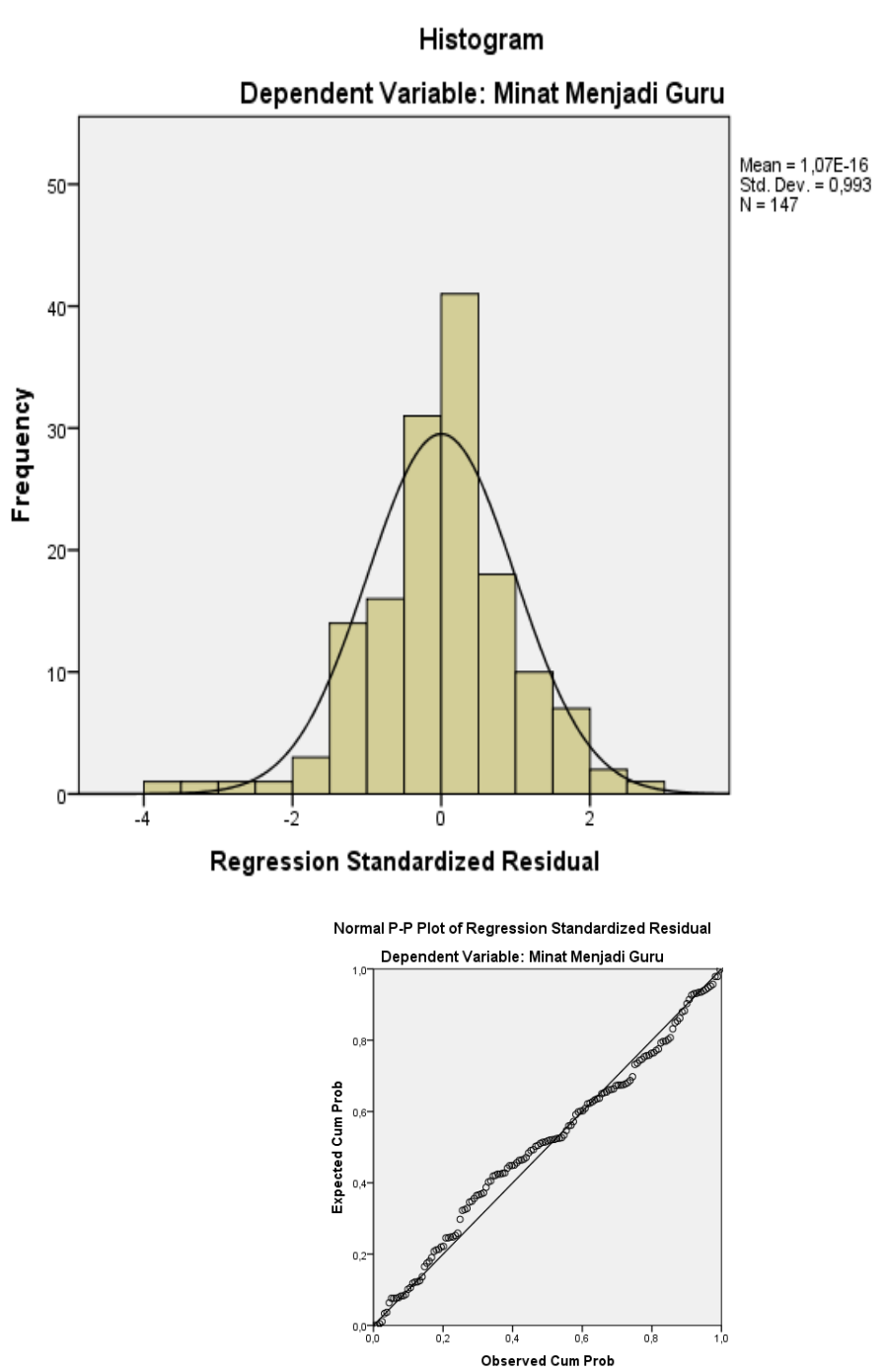

Jika data ploting (titik-titik) yang menggambarkan data sesungguhnya mengikuti garis diagonal maka model regresi dikatakan berdistribusi normal, atau dapat dilihat dari histogram menyerupai lonceng terbuka kebawah. 


\section{Uji Multikolinieritas}

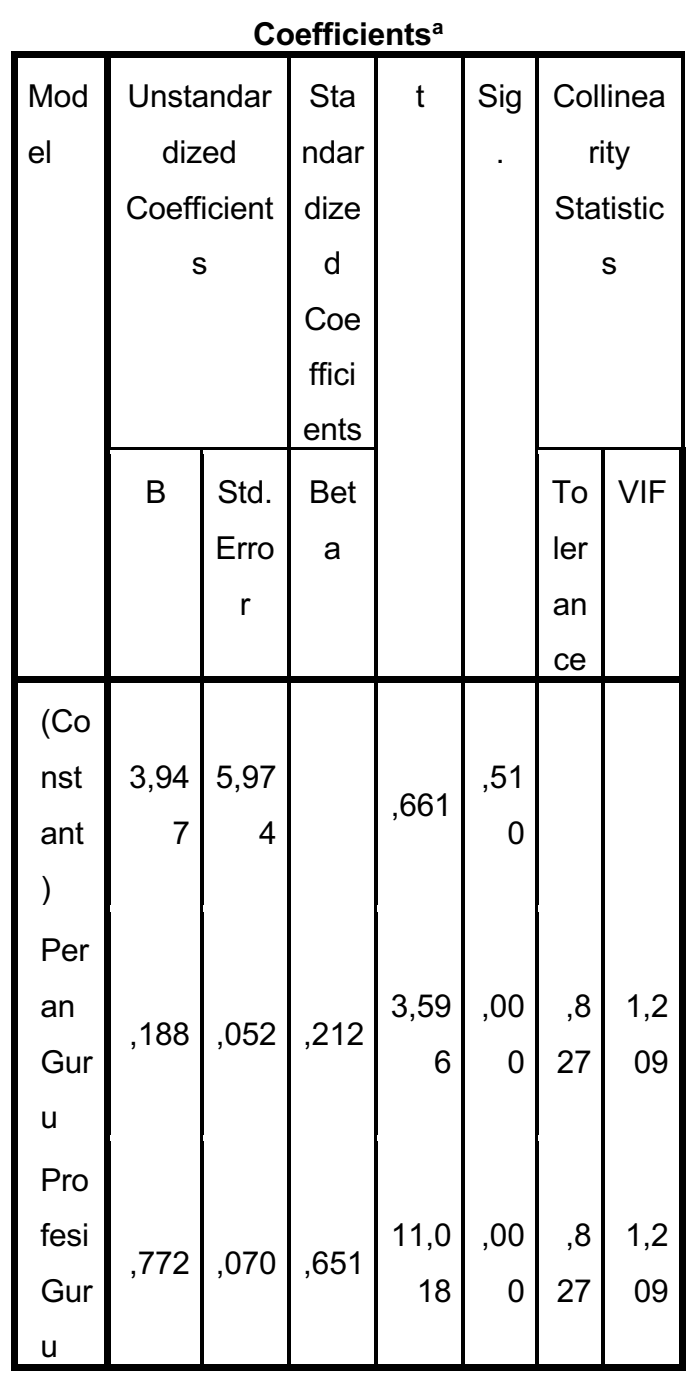

a. Dependent Variable: Minat Menjadi Guru

Jika Nilai Tolerance $>0,100$ dan nilai VIF $<10,00$, maka tidak terjadi gejala multikolinieritas. Dari table diatas diperoleh nilai tolerance $0.827>0,100$

\section{.multikolinieritas}

\section{Uji Heteroskedastisitas,}

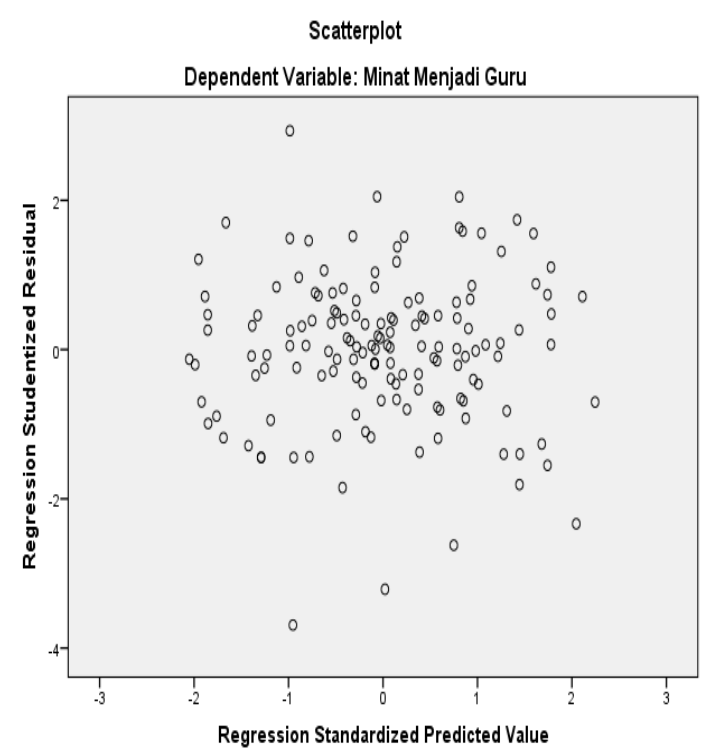

Jika Tidak ada pola yang jelas (bergelombang, melebar kemudian menyempit) pada gambar scatterplots, serta titik-titik menyebar di atas dan dibawah angka 0 pada sumbu y, maka tidak terjadi heteroskedastisitas. Dari scatterplots diatas terlihat acak dan random, tidak terlihat pola tertentu dan titik-titik berada diatas dan dibawah nilai 0 sumbu y, maka dapat disimpulkan tidak terjadi heteroskedastisitas.

\section{Uji Autokorelasi}

\begin{tabular}{|l|c|c|c|c|c|}
\hline \multicolumn{5}{|c|}{ Model Summary } \\
\hline M & R & R & Adjuste & Std. Error & Durbin- \\
o & & Squar & d R & of the & Watson \\
d & & e & Square & Estimate & \\
e & & & & & \\
I & & & & & \\
\hline
\end{tabular}




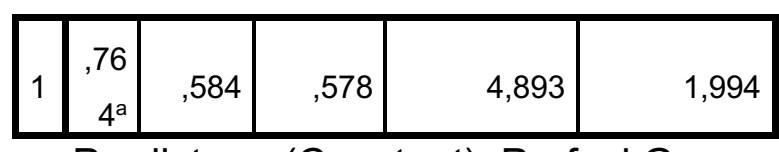

a. Predictors: (Constant), Profesi Guru, Peran Guru

b. Dependent Variable: Minat Menjadi Guru

Jika Nilai Durbin Watson terletak antara du sampai dengan ( $4-\mathrm{du}$ ), maka tidak ada gejala autokorelasi. Nilai du terletak pada table Durbin Watson untuk alpha 0,05 dengan $k=2$ dan $N=147$. Dari table Durbin Watson diperoleh 1,7581 untuk $\mathrm{k}=2$ dan $\mathrm{N}=147$. Tinggak kita bandingkan ternyata diperoleh $\mathrm{du}(1,7581)<$ Durbin-Watson $(1,994)<$ $d u$ - 4(2,2419). Dari hasil tersebut disimpulkan bahwa tidak ada gejala autokorelasi

Dari Hasil Uji Asumsi Klasik disimpulkan bawha Regresi Linier Berganda,memenuhi Uji Asumsi Klasik dan dapat diteruskan dengan

\section{Uji Hipotesis}

\section{UJI HIPOTESIS}

Untuk Uji Hipotesis 1 dan 2 kita dapat melihat table outpot berikut

Coefficients $^{\mathrm{a}}$

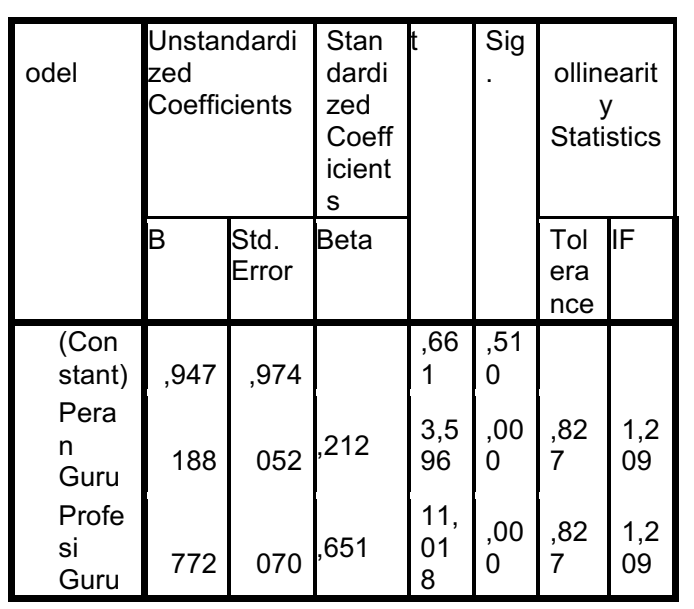

a. Dependent Variable:

Minat Menjadi Guru

Jika Nilai sig < 0,05 pada table t maka artinya variable independent (X) secara parsial terhadap variable dependent (Y). dari tabel diatas diperoleh prean Guru (X1) memiliki nilai signifikansi $0,00<0,05$ dan Profesi Guru (X2) memiliki nilai signifikansi yang sama $0,00<0,05$ dapat disimpulkan dari hasil tersebut :

1. Terdapat pengaruh positif persepsi siswa SMA/SMK tentang peran guru terhadap minat menjadi guru.

2. Terdapat pengaruh positif persepsi siswa SMA/SMK tentang profesi guru terhadap minat siswa menjadi guru.

Uji Hipotesis ke 3 ( Uji F Simultan ) Untuk uji ke 3 kita melihat table berikut : 


\begin{tabular}{|r|r|r|r|l|l|}
\hline Model & $\begin{array}{l}\text { Sum of } \\
\text { Squares }\end{array}$ & df & $\begin{array}{l}\text { Mean } \\
\text { Squar } \\
\text { e }\end{array}$ & F & Sig. \\
\hline $\begin{array}{l}\text { Re } \\
\text { gr } \\
\text { es } \\
\text { sio } \\
\mathrm{n}\end{array}$ & 844,397 & & $\begin{array}{r}422,1 \\
98\end{array}$ & 167 & $000^{\mathrm{b}}$ \\
$\begin{array}{r}\text { Re } \\
\text { sid }\end{array}$ & 447,740 & 44 & 3,943 & & \\
ual & & & & & \\
Tot & & & & & \\
al & 292,136 & 46 & & & \\
\hline
\end{tabular}

a. Dependent Variable:

Minat Menjadi Guru

b. Predictors: (Constant),

Profesi Guru, Peran Guru

Jika Nilai Sig < 0,05 pada table diatas maka artinya variable independent $(X)$ secara simultas berpengaruh positif terhadap variable dependent (Y). Dari table diatas diperoleh nilai sig $0,00<$ 0,05 maka dapat disimpulkan sebagai berikut :

3. Terdapat pengaruh positif Persepsi siswa SMA/SMK tentang peran guru dan persepsi siswa tentang profesi guru terhadap minat siswa menjadi guru.

\section{PEMBAHASAN}

1. Pengaruh persepsi siswa SMA/SMK tentang peran guru terhadap minat siswa menjadi guru.

Pengaruh persepsi siswa SMA/SMK tentang peran guru terhadap minat menjadi guru memiliki katagori sangat kuat, hal ini ditunjang dengan hasil wawancara bahwa Peran guru memiliki pengaruh yang kuat terhadap persepsi siswa, dimana dikala guru memerankan perannya dalam mengajar, secara teoritis sebagai guru yang efektif senantiasa memberikan bimbingan dan arahan pada siswanya, prilaku guru sebagai pembimbing sangatlah berpengaruh kuat terhadap persepsi siswa. Siswa SMA/SMK sesuai usianya sangat membutuhkan peran guru sebagai pembimbing yang baik dan benar, karena peran guru tersebut dapat menjadi model bagi siswanya serta dengan kemampuan pendekatan yang tepat, menimbulkan kepercayaan kepada siswa, bahwa menjadi seorang guru itu sesuatu yang mulia.

Peran guru sebagai motivator memberikan pengaruh berikutnya terhadap persepsi siswa, dimana siswa SMA/SMK sedang membutukan wawasan ke masa 
depan untuk melanjutkan langkah selanjutnya, apakah siswa tertarik melanjutkan kuliah atau tidak, jika akan melanjutkan pemilihan program studi yang dipilih ditentukan oleh persepsi siswa itu sendiri. Bagaimana seorang guru berperan memotivasi siswa dapat mempengaruhi persepsi siswa akan ketertarikan terhadap profesi guru.

Peran guru sebagai sumber belajar merupakan hal yang mempengaruhi persespsi siswa berikutnya, dimana kemampuan guru dalam memberikan wawasan pengetahuan kepada siswa menjadi penilaian tersendiri bagi siswa yang dapat memberikan kepercayaan pada diri siswa bahwa apa yang disampaikan guru itu adalah pengetahuan yang berharga yang perlu siswa ketahui dan pelajari. Apa yang dijelaskan Guru memberikan rasa ingin tahu yang tinggi bagi siswa. Secara tidak langsung dapat mempengaruhi persepsi siswa bahwa menjadi seorang guru memerlukan wawasan pengetahuan yang tinggi agar dapat membelajarkan siswanya dengan jelas dan sesuai dengan harapan dan kebutuahan siswa akan pengetahuan.

\section{Pengaruh persepsi siswa SMA/SMK tentang profesi guru terhadap minat siswa menjadi guru}

Berdasarkan hasil pengolahan data diperoleh hasil bahwa terdapat pengaruh positif persepsi siswa siswa SMA/SMK tentang profesi guru terhadap minat siswa menjadi guru. Dengan nilai signifikansi $0,00<$ 0,05 tentang Profesi Guru (X2). Berdasarkan hasil wawancara dengan beberapa guru dan beberapa siswa diperoleh informasi bahwa persepsi positif siswa tentang profesi guru yang paling berpengaruh adalah pada kemampuan guru yang memiliki ketrampilan mengajar yang baik, bagaimana guru menyampaikan materi pembelajaran dengan menggunakan strategi pembelajaran yang tepat dan menyenangkan, dimana proses mempelajari materi pengajaran tidak dirasakan membebani siswa tetapi sebaliknya siswa merasa bahwa pengetahuan tersebut 
adalah sesuatu yang ingin siswa ketahui, dan mendapat jawaban dari masalah. Pemilihan Strategi pembelajaran yang tepat, tidak monoton dan menyenangkan, adalah harapan siswa, dengan demikian guru yang mampu melakukan pemilihan strategi pembelajaran yang tepat dan menyenangkan adalah guru yang dapat memberikan pengaruh terhadap persepsi siswa tentang profesi guru, dan meiliki minat menjadi guru.

\section{E. Kesimpulan}

Berdasarkan hasil penelitian dan pembahasan, maka dapat ditarik kesimpulan, sebagai berikut:

Terdapat pengaruh positif dan signifikan persepsi siswa tentang peran guru terhadap minat siswa menjadi guru, dibuktikan dengan hasil standar koefisien 0,212 dengan nilai $t$ sebesar 3,596 dan signifikansi 0,00, hal ini mengandung arti semakin tinggi persepsi mahasiswa tentang peran guru, semakin tinggi pula minat menjadi guru atau sebaliknya. Sumbangan efektif dari variable ini sejumlah 21,2 \% terhadap perubahan variable minat siswa menjadi guru.

Terdapat pengaruh positif dan signifikan persepsi siswa tentang profesi guru terhadap minat siswa menjadi guru, dibuktikan dengan hasil standar koefisien 0,651 dengan nilai $t$ sebesar 11,018 dan signifikansi 0,00, hal ini mengandung arti semakin tinggi persepsi mahasiswa tentang profesi guru, semakin tinggi pula minat siswa menjadi guru. Sumbangan efektif dari variable ini sejumlah $65,1 \%$ terhadap perubahan variable minat siswa menjadi guru.

Dari kedua variable persepsi siswa tentang peran guru dan persepsi siawa tentang profesi guru memiliki pengaruh positif dan signifikan terhadap minat siswa menjadi guru. Dibuktikan dengan nilai $F$ hitung sebesar 101,167 dengan nilai signifikansi sebesar 0,00 sedangkan besarnya nilai koefisien determinasi $\left(R^{2}\right)$ sebesar 0,578 atau $57,8 \%$. Hal ini mengandung arti bahwa variabel minat siswa menjadi guru dapat dipengaruhi oleh persepsi siswa tentang peran guru dan profesi guru sedangkan sisanya $42,2 \%$ dijelaskan oleh variabel lain yang tidak diteliti dalam penelitian ini.

Kesimpulan akhir yang diperoleh dalam penelitian dan saran perbaikan yang dianggap perlu ataupun penelitian lanjutan yang relevan. 


\section{DAFTAR PUSTAKA}

Kemendikbud.(2017).Kemendikbud dan Asosiasi Profesi Guru bersama-sama Jawab Persoalan Guru. Diakses tangga; 11 Februari 2018.

Febriana, Rina (2018). Kompetensi Guru, Jakarta : Bumi Aksara

Sukmadinata . Nana Syaodih, (2011), Landasan Psikologi Proses Pendidikan, Bandung : Remaja Rosdakarya

Sugiyono.(2015). Metode Penelitian Pendidikan:Pendekatan

Kuantitatif, Kualitatif dan R\&D. Bandung: Alfabeta.

Wina Sanjaya. (2008). Strategi Pembelajaran Berorientasi Standar Proses Pendidikan. Jakarta: Kencana

Suharsimi Arikunto. (2013). Dasardasar Evaluasi Pendidikan. Jakarta : Bumi Aksara.

Slameto. (2003). Belajar dan factorfaktor yang mempengaruhinya. Jakarta: PT Rineka Cipta.

Dedi Supriadi.(2001). Reformasi Pendidikan dalam Konteks Otonomi Daerah. Yogyakarta: Adicita Karya Nusa

Winkel, W.S. (2004). Psikologi Pengajaran. Edisi Revisi. Jakarta: Grasindo

Anderson, L. W., \& Krathwohl, D. R. 2010. Kerangka Landasan untuk Pembelajaran, Pengajaran, dan Asesmen. Yogyakarta: Pustaka Pelajar.

Saifuddin Azwar.(2008). Sikap Manusia: Teori dan Pengukurannya. Yogyakarta: Pelajar.

artikel "Minat Siswa Jadi Guru Minim, JPPI Khawatirkan Rendahnya Mutu Guru", https://tirto.id/dti5

Muh. Nasrullah,(2018). Minat Menjadi Guru Pada Mahasiswa Program
Studi Pendidikan Administrasi Perkantoran Fakultas IImu Sosial Universitas Negeri Makassar; dipublikasikan: 30Juni-2018 